\title{
PROBLEMS IN READING ACQUISITION IN A SECOND OR A FOREIGN LANGUAGE
}

Anja Zorman, PhD

Faculty of Humanities

University of Primorska (Slovenia)

e-mail: anja.zorman@guest.arnes.si

\begin{abstract}
A b s tract
Literacy is a cultural value of individuals and society, and as such it is an essential factor of quality and creative life in modern society. Literacy acquisition is thus an irreplaceable content of first, second and foreign language learning. In the paper, the author presents problems that occur in multilingual literacy acquisition based on contrastive error analysis of written materials produced in the writer's second or foreign language. Data from the contrastive error analysis were used to draw guidelines for second/foreign language literacy instruction and a theoretical model of multilingual literacy development that has been verified empirically. The basic finding is that literacy acquisition in a second/foreign language as well as in the first language must be a systematic learning process assisted by adults aware of the stages and mechanisms that allow students to progress to quality higher levels.
\end{abstract}

Key words: early literacy, first language, second language, foreign language, early literacy teaching methods, phonological awareness, phonological-graphical method, contrastive analysis

\section{Introduction}

Linguistic competences a child develops at school are interrelated. The level of linguistic and communicative competence he achieves in the second and/or foreign language is therefore partially in function of the competence level he had achieved in his first language before he began to be intensively exposed to the second and/or foreign language (Cummins, 2000). Literacy development in a second/foreign language is thus related to reading related competences, abilities and knowledge that have already been developed in the reader's first language.

In bilingual or multilingual literacy acquisition children develop different cognitive structures in comparison to cognitive structures developed by children that learn to read and write in a single language. Durgunoglu (2002) explains that in bi- and multilingual literacy acquisition children develop two types of writing representation as a means speech representation. The first type refers to reading related concepts and reading strategies that are common to all languages, or rather, concepts and strategies 
that function equally in all languages (language universals). These partial reading competences transfer from the child's first language to all languages he is exposed to. The second type of representations refers to language specific concepts such as phoneme-grapheme correspondences.

When learning to read and write in a second/foreign language, knowledge abilities and competences that have already been developed in the first language are transferred to new learning either promoting (positive transfer) or impeding learning (negative transfer). In organized reading instruction a greater attention is thus drawn to differences between languages as to prevent or at least limit as far as possible the inadequate transfer of previous knowledge from the first to the second/foreign language. It is crucial that teachers and other adults assisting children in reading acquisition are aware of the differences in the phonology and spelling conventions of the two languages. Only a firm knowledge of these differences enables teachers to understand why mistakes occur and to decide how to further develop literacy instruction effectively.

\section{Areas of inadequate inter-linguistic transfer (negative transfer)}

In consequent bilingual or multilingual literacy acquisition ${ }^{1}$ inadequate transfer in reading and writing in second and/or foreign language occurs in the following areas: phonology (discriminative listening and pronunciation, 1.1 and 1.2), phonologicalgraphical knowledge (phoneme-grapheme correspondences, 1.3) and second and/or foreign language spelling conventions (for example, the use of capital letters, punctuation, accent, apostrophe etc.).

\section{Phonological discrimination and pronunciation}

To a deeper understanding of processes that occur in second/foreign language (literacy) acquisition it is crucial that adults assisting children in this learning process are aware of the inadequate impact of the learner's first language and other languages he has been exposed to on learning how to read and write in the second/foreign language taught (the target language) as well as of the reasons for their occurrence.

The phonological discrimination ability is innate to human beings. When learning to speak children discriminate speech from other sounds perceivable in their environment.

Contemporary studies, particularly neurolinguistic studies (for example, Kuhl, 2004; Kuhl, et al., 2003; Maye and Weiss, 2003; Iverson et al., 2002; Werker and Tees, 1984) have shown that the ability to discriminate sounds allows babies to recognize sounds of all languages, irrespective of their specific linguistic experience (exposure to L1 or LL1). In the following stages of speech acquisition, at the latest at the age of 12

\footnotetext{
${ }^{1}$ Children may receive simultaneous literacy instruction (for example, in Slovene-Hungarian bilingual model in Prekmurje in Slovenia), or even literacy instruction in second language first and consequently in their first language (for example on Malta).
} 
months, this ability undergoes modification, or rather it adapts to the child's linguistic environment. Older children and adults thus often have difficulties in discriminating foreign languages' phonological contrasts that have no contrastive value in their first language(s), (Maye and Weiss, 2003). These studies have proven that perceptiveneurological abilities do not vanish with age, but rather they undergo various modifications in perceptive strategies and language processing strategies as to adapt to the child's first language(s) phonology. A language specific phonology contrasts only particular subgroups of phonological contrasts. For example, Italian speakers discriminate easily geminate consonants from single ones, voiceless and voiced dental alveolar affricate phonemes /z/ and /dz/, close-mid and open-mid vowels / / / - /e/ and / / / $/$ - /o/. But they will probably have difficulties to discriminate between $/ 3 /$ and $/ \mathrm{d} 3 /$ (Slovene), /d/ and / $/ \Theta /$ English), / $/ /$ and / $/ \mathbf{r} /$ (Czech) because of the absence of these contrasts in Italian. Iverson et al. (2002) claim that listening discrimination ability development is based on changes in processing phonological information (rather than perception itself) that adapts from language-general to the phonology of the specific language of the child's environment.

Second and/or foreign language speech perception in older children and adults is largely determined by the phonology of their first language(s). Particularly in initial contacts with a second and/or foreign language, auditory perception and pronunciation of phonemes that differ from a person's first language(s) is adapted to the existing phonology (Ur, 1996). In the following sections of the paper the adaptation of L1-L2/LS divergent phonemes to the auditory perception and pronunciation to the existing L1 phonology is presented by means of examples of Italian pronunciation on the part of Slovene speakers (A. and B.) and pronunciation of various languages on the part of Italian speakers (C., D., E. and F.)

\section{A. Geminate phonemes}

A typical adaptation made by Slovene speakers in the pronunciation of geminate phonemes (absent in the Slovene phonology) is degemination. At the age of three and a half my daughter degeminated the Italian phoneme /rr/ in the word terra (Eng. ground) to /r/ while singing the Italian song Girotondo:

(1) ['tera] instead of ['terra].

A very interesting adaptation occurred with geminated trill and lateral phonemes $/ \mathrm{rr} / \mathrm{and} / \mathrm{ll} / \mathrm{.}$ Instead of degeminating them she replaced them with consonant groups made of the (originally geminated) trill or lateral + occlusive /d/:

(2) [ba'rilda] instead of [ba'rilla] Barilla (Italian pasta trade mark);

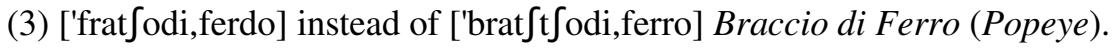

\section{B. Diphthong and hiatus}

Slovene speakers typically adapt the pronunciation of diphthongs and hiati in the following ways: 
(i) Approximants $[\mathrm{w}]$ and $[\mathrm{j}]$ and semi-vowels $[\mathrm{u}]$ and [i] are simplified to vowels $[\mathrm{u}]$ and [i] respectively followed by [v] and [j] respectively. For example:

(4) [e'manuvel] instead of [e'manwel] Emanuel (male first name); ['duve] instead of ['due] due (numeral);

(5) [mijo] instead of [mio] mio (pronoun/adjective).

(ii) The second type of adaptation consists in the substitution of the semi-vowel $/ \mathrm{w} /$ in the diphthong and hiatus with the fricative $/ \mathrm{v} /{ }^{2}$ :

(6) ['kvesto] instead of ['kwesto] questo (pronoun/adjective); [kvi] instead of [kwi] qui (adverb).

\section{Voiceless pronunciation of $/$ s/ in intervocalic position}

In Italian, the grapheme $S$ has voiced pronunciation in intervocalic position (except for some dialects in which the pronunciation is voiceless). In intervocalic position is has a voiceless pronunciation when geminated /ss/. To preserve the original voiceless pronunciation of the grapheme $S$ in the name of the Greek football club Galatasaray, Italians adapted the spelling to Galatassaray by geminating the sound /ss/:

(7) [galatassa'raj] instead of [galatasa'raj].

\section{Pronunciation of the word-initial grapheme $S$}

In Italian, at the beginning of words grapheme $\mathrm{S}$ has voiced pronunciation $/ \mathrm{z} /$ when followed by a voiced consonant $/ \mathrm{b} /, / \mathrm{d} /, / \mathrm{g} /, / \mathrm{l} /, / \mathrm{m} /, / \mathrm{n} /$ or $/ \mathrm{v} /$ (for example, ['zlitta]slitta (sleigh)); when followed by voiceless consonants and vowels it has a voiceless pronunciation /s/ (for example, ['skatola] scatola (box) and ['sole]sole (sun). The pronunciation of loan words and foreign words on the part of Italian speakers thus undergoes the adaptation to the Italian phonology:

(8) [zmajlə] instead of [smajl]smile, [zlimə] instead of [slim]slim vs. [stopə]stop, [skanə]scan, [sportə]sport (all examples are loan words from English).

\section{E. Elision of the phoneme /h/}

The Italian phonology does not include the phoneme $/ \mathrm{h} /$, except for Tuscan dialect. Consequently, Italians have great difficulties with its pronunciation with a tendency to elide it:

(9) ['हvə] instead of [hæv] En. have.

\section{F. Short mid vowel/a/ addition}

Addition of vowels or semi-vowels in inter-syllabic position with a syllabic complex structure or in the word-final position (Latino effect, McGuinness and McGuinness, 1998) is Romance languages related phenomenon. Romance languages

${ }^{2}$ Perhaps reinforced by German pronunciation, for example, Ger. bequem [be'kvem]. 
have typically a relatively simple syllabic structure with rare occurrence of three- or more consonant groups and the prevailing open syllable CV. The Latino effect is observable also in the pronunciation of Italian words in some Italian dialects, particularly in the south of Italy ${ }^{3}$ :

(10) [skanə] instead of [skæn] En. scan;

(11) [pisi'kologo] instead of [psi'kologo] it. psicologo (psychologist).

Adaptation to a new phonology is relatively rapid with adults (Tsukada, 2004) ${ }^{4}$ as well as with children (Kuhl et al., 2003; Čok, 1995), under the condition that the contact with the second/foreign language phonology is direct (Kuhl, 2004; Kuhl et al., 2003; Maye and Weiss, 2004). Auditory contact with a second/foreign language merely through media such as television or radio has no particular impact on the development of phonological discrimination and pronunciation (Kuhl, 2004; Kuhl et al., 2003).

Impact of phonology already existing in an individual on auditory perception and pronunciation of new, unknown phonemes is obvious. In interaction of different languages, existing knowledge is transferred to new communicative acts, where these actions are either successful (positive transfer) ${ }^{5}$ or false (negative transfer). The relation between the positive and negative transfer depends largely on the degree of correspondence between the two phonologies, on the quantity and quality of contact with the second/foreign language as well as individual's specific phonological discrimination abilities.

\section{Phonological-graphical awareness}

The term phonological-graphical awareness refers to the knowledge of correspondences between phonemes and graphemes in a specific language. As such it implies:

- Knowledge of the language phonology;

- Knowledge of graphemes of a specific language;

${ }^{3}$ In the past, a so-called »prosthetic $\mathrm{i} \ll$ was added to words with a consonant group at the beginning of words that followed a word ending in a consonant as to facilitate the pronunciation, for example, in per istrada; today the use of "prosthetic $\mathrm{i}$ « is almost extinguished and replaced by forms such as per strada.

${ }^{4}$ In a study conducted by Tsukada (2004) bilingual Thai-English speakers who had moved from Thailand to Australia showed equal auditory perceptive and pronunciation abilities in English, irrespective of the length of their permanence in an English-speaking area that varied between 2 months and 30 years (with average permanence 5.5 years).

${ }^{5}$ In a comparative study of bilingual Thai-English and monolingual English speaking adults, a positive transfer was observed even in individuals that were not speakers of the target language (Korean). The pronunciation of the selected phonemes is similar in Korean and Thai, differing largely from the pronunciation in English.Coherently with the (non-)correspondence of phonological characteristics of the languages observed, bilingual Thai-English speaking adults who were native speakers of Thai achieved higher results than monolingual English speakers and the difference between the two groups was statistically significant. The study author interpreted these results in terms of the positive transfer Thai-English speakers made from Thai to Korean (Tsukada, 2004). 
- Understanding that these graphemes are either simple (a phoneme is represented by one letter) or complex (a phoneme is represented by a group of letters like TH in this ['Өis], $\mathrm{CH}$ in chin['t $\mathrm{fin}$ ] in English or $\mathrm{CH}$ in chiave ['kjave], $\mathrm{SCI}$ in scialle [' $\left.\int a l l e\right]$ in Italian); ${ }^{6}$

- Awareness on multiple representation of a phoneme: individual phonemes may be represented by various graphemes (for example, in English the phoneme /i/ may be represented by graphemes EE, EA, Y: green, team, happy; similarly, in Italian the phoneme $/ \mathrm{k} /$ may be represented by graphemes $\mathrm{C}, \mathrm{CH}, \mathrm{Q}$ or $\mathrm{CQ}$ : cane, chiave, quando, acqua; in Slovene the phoneme /uيn/ may be represented by graphemes U, L in V: ušel, žolna, vlak);

- Awareness on multiple representations of graphemes: individual graphemes may be used to represent various phonemes (for example, in English the grapheme O may represent the phoneme /o/ in hot and /oe/ in most; in Italian the grapheme G may be used to represent the phoneme $/ \mathrm{g} /$ in gatto and $/ \mathrm{dZ} /$ in gelato; in Slovene the grapheme $\mathrm{L}$ may represent the phoneme $/ \mathrm{l} / \mathrm{in} \mathrm{val}$ and / $/ \mathrm{\Lambda} /$ in volna $)^{8}$

Mistakes in second and/or foreign language written coding may thus be ascribed either to inadequate auditory perception, lack of knowledge or poor knowledge of spelling conventions of the target language and/or inadequate transfer of knowledge from the first language(s) to second/foreign language(s) (negative transfer). Usually, the causes are interrelated. A person with poor auditory perceptive abilities in a second/foreign language, codes wrongly, has poor knowledge of spelling conventions (quite often in his first language(s) as well) and tries to solve these problems by transferring already existing knowledge in his first language(s) to the language he learns. In some cases, these problems may also originate in general or specific learning disabilities.

The impact of the first language is observable even in individuals with no particular difficulties with writing in second/foreign languages, indicating the extremely important role of a child's early development on all further learning and functioning in general.

Negative transfer analysis presented in the following sections was performed on the corpus of (i) records made by my daughter as spontaneous coding in Italian during the early period of her literacy development (S), ${ }^{9}$ (ii) 357 pages of written papers by the

\footnotetext{
${ }^{6}$ This concept's comprehension may be verified by means of a simple test. Children are shown three images: a square, a triangle and a square with a triangle above the square. Children usually react by recognizing the third image as a house thus showing the awareness that signs have different meanings when combined and separated from one another (McGuinness and McGuinness, 1998: 15).

${ }^{7}$ McGuinness and McGuinness (1998: 16) have proven that 7 or 8-year-old children are able to comprehend and recall various symbols functioning as signifiers of the same referent.

${ }^{8}$ Comprehension of this concept is tested by means of a circle test. Children are shown a drawing of a coloured circle and ask children what it might represent. In the study by McGuinness in McGuinness (1998: 16) most children answered the drawing might represent a ball or a circle.

${ }^{9}$ My daughter was observed during the period between the ages five and a half and six and a half. In the development of the alphabetic writing system awareness she had reached the highest level,
} 
first year students of the Faculty of Education in Koper, class teacher study program $(\mathrm{ST})^{10}$, (iii) commercial and information material, packaging, and other written materials (G). Examples refer to the negative transfer from Slovene to Italian.

\section{Negative transfer from Slovene to Italian}

Negative transfer from Slovene to written coding in Italian shows in inadequate writing of geminate phonemes (16), phonemes /k/ (17), /t $\int /(18), / \mathrm{d} 3 /(19), / \mathrm{z} /(20), / \mathrm{ts} /$ (21), semi-consonants $/ \mathrm{w} /$ in $/ \mathrm{j} /$ in the diphthong (22), vowels (23), consonant group NS- of Latin origin (24):

(16) ČALO instead of giallo (S), ŽOVANA instead of Giovanna (S), ATRICE instead of attrice (ST). ${ }^{11}$

In geminate phonemes error analysis, it is hard to draw the line between auditory and spelling negative transfer. In Italian, contrasts between geminate and plain consonants have phonological value while in Slovene this is not the case. Consequently, in Slovene speakers, auditory discrimination and therefore pronunciation and spelling may be reduced. It can be claimed with the highest degree of certainty that errors result from negative transfer from Slovene spelling system only in records made by my daughter. She pronounced correctly geminate phonemes in giallo and in Giovanna, but she adapted their spelling to the existing knowledge of correspondences between phonemes and graphemes. When asked why a record on another drawing contained

the level of alphabetic hypothesis. Occasionally, mistakes such as grapheme reduction (ČOKLADA), premeščanja (SRENČO NOVO LETO 2005), substitution (KURITE KREMICO) and a combination af mistakes (HOBINTICA; KOČIJA ZA BRABRIKE; A E I O U MAME NI DOMU PAPRIŠLA BOIN PRSNESLA BONBNČKE IN ČOKOADE) still occured, principally she coded according to auditory perception without any attention to spelling rules (KONIČEK; LABOT; TERME ČATEŠ; SNEK; DEDEK MRAS). At the age of five years and eight months began to be interested in spelling rules: "Mom, how is vesel written? With a final U or V? « $(5,10)$, use of punctiation, where her hypotheses more or less differed from the spelling conventions (LUNA IN LIZA SE TOŠIRATA JE PORTKALO NA VRATIH KDO JEPRIŠU PATRIK; PO VEŽI OT PIKE, DO, PIKE NATO ŠE PO BARVAJ; TE POVABIM NA, ROJSTNI, DAN; OTBRI IN POGLEJ). All recordings were written with capital letters, they were linear and were not mirror writings (occasionally individual letters were dissymetrical, especially at the beginning of the observation). They were produced spontaneously.

${ }^{10}$ Written papers were selected as analysis corpus intentionally since they are students' individual works where their attention is directed primarilly in the contents what allows the verification of the acquired knowledge and not merely learned knowledge as is true of the spelling competence testing by means of a dictation. The fact that students had been informed in advance that the papers were giong to be assessed, including spelling, enhances the level of spelling quality of the papers. Texts were written mostly on a computer or typing machine, they were partially written by hand.

${ }^{11}$ In the analysed corpus 322 errors $(73 \%)$ of all geminate phonemes related errors concerned reduction, 73 errors $(23 \%)$ concerned addition and 14 errors $(4 \%)$ concerned shifting (for example,. *tapetto namesto tappeto). The most problematic resulted the phomene /t/ with almost a fourth of all geminate related errors. 
geminate MM in MAMMA she would respond that she had been instructed to do so by her nursery-school teacher. ${ }^{12}$

(17) DOMENIKA instead of domenica (S), NIKOLA instead of Nicola (ST), KONOSCIUTO instead of conosciuto (ST), AQUA instead of acqua $(\mathrm{G})$; $^{13}$

(18) DOLČI instead of dolci (ST).

This group of errors originates from a multiplicity of graphemes used to represent a single phoneme in Italian and as such they typically occur with Italian native speakers as well. A more detailed analysis of errors shows that these derive mostly from a poor knowledge of a spelling rule with a few exceptions related to the negative transfer. The occurrence of these errors is nevertheless interesting, since students had passed the maturity exam in Italian as a subject (and have thus reached the B1 level according to the CEFR), and they had been informed that the papers were going to be assessed, where at least one of the criteria was linguistic competence, including spelling.

(19) JAPONESE instead of giapponese (ST).

In the case of JAPONESE, negative transfer occurs unquestionably but it probably originates in similarities in Italian and English phonological representations [dzappo'nese] and ['dzæpəniz] rather than Slovene, however the negative transfer from English is certainly reinforced by the Slovene spelling japonski.

(20) FILOZOFICA instead of filosofica (ST), ANALIZI instead of analisi (ST) FAZE instead of fase (ST), ILLUMINIZMO instead of Illuminismo (ST);

(21) FUNCIONARE instead of funzionare (ST), ESSENCIALI instead of essenziali (ST) SOMIGLIANCE instead of somiglianze (ST), SCERCOSO instead of scherzoso;

(22) BIBLIOGRAFIJA instead of biliografia (ST), AVTOMOBILI instead of automobili (ST).

Recordings in the above group most clearly reveal the direct transfer of Slovene graphemes $\mathrm{Z}, \mathrm{C}$, J in $\mathrm{V}$ where according to the Italian spelling system $\mathrm{S}, \mathrm{Z}$, I in $\mathrm{U}$ should be used to represent phonemes /z/, /ts/, /j/ and /w/.

(23) ARGUMENTO instead of argomento (ST), DEMONSTRARE instead of dimostrare (ST), REDUTTIVA instead of riduttiva (ST), RESPOSTE instead of risposte (ST), REVOLUZIONARIA instead of rivoluzionaria (ST), LITTERATURA instead of letteratura (ST);

(24) KONSTRINGERE instead of costringere (ST), ${ }^{14}$ CONSTANTEMENTE instead of costantemente (ST), CONSTRUITE instead of costruite (ST), INSTITUTO

\footnotetext{
${ }^{12}$ Interestingly, it seems that spelling had a particular impact on pronunciation as well since she articulated the geminate $/ \mathrm{mm}$ / with a stronger emphasis when reading the inscription MAMMA.

${ }^{13}$ This example has been classified as negative transfer since in Slovenia occur numerous English and pseudo-English inscriptions with the word aqua taken directly from Latin (for example, Aquafresh toothpaste, Aquapark, Aqualand, Aqualuna swimming-pools etc.), having indirect impact on writing in Italian. Similarly, the writing of English words would be Brite Liner (marker trade mark) instead of Bright Liner, isy-pil (Rio Mare tuna can opening system) instead of easy peel.
} 
instead of istituto (ST), INSTANTE instead of istante (ST), DEMONSTRARE instead of dimostrare (ST), TRANSFERITI instead of trasferiti INSTINTIVAMENTE instead of istintivamente (ST), TRANSLATO instead of traslato (ST), INSTRUZIONE instead ofistruzione $(\mathrm{G}){ }^{15}$

Examples stated in (23) and (24) contain words of Latin origin that have had a different development into Italian on one hand and Slovene, English and some other languages on the other hand. ${ }^{16}$ Errors type DEMONSTRARE thus originate from the negative transfer from Slovene (first language) or English (first foreign language) or from a combination of both: transfer from one language is reinforced by the correspondence in the other language. Furthermore, forms such as †constringere, $\dagger$ demonstrare, $\dagger$ transferire and $\dagger$ translato remained in use in Italian for a long time and in some cases both forms co-exist even today, for example constatare and costatare. Moreover, in modern Italian there is a large number of words containing the consonant group -ns-, contributing additionally to instability in representation of consonant groups of Latin origin.

A very interesting conclusion on error analysis comes from a study performed by Durgunogluet al. (2002) who studied writing strategies of bilingual Spanish-English speaking children. The basic feature common to all records analysed was a tendency to writing economy resulting in a common, Spanish-English writing system with the highest possible level of correspondence between phonemes and graphemes. Records showed a systematic use of phoneme-grapheme correspondences where children coded words according to auditory perception rather than spelling conventions of either English or Spanish. They transferred the alphabetic strategy, typical of Spanish, to writing in English as to code words such as read, need, witch, wardrobe, favourite, that and adventures as rid, nid, with, worldrol, favret, thet in adengers. And vice versa, they used writing according to auditory perception strategy to code in Spanish as well by eliding letters with diacritic function and adapting writing otherwise as well (for example, ago, asemos in aser instead of hago, hacemos, hacer), and used typically English consonant groups instead of Spanish (scuela, stay, spero, studios, different instead of esceula, estoy, espero, estudios, diferent).

\footnotetext{
${ }^{14}$ More likely by analogy with better known borrowings konstrukcija, konstitucija, konservativen etc. than direct transfer from borrowings konstrikcija, konstriktor.

${ }^{15}$ From the analysed corpus the consonant group -ns- emerges as the most problematic (particularly when it follows the vowel /i/ and when it precedes the consonant / $/$ /), although a number of consonant groups of Latin origin had a different phonological development in Italian and Slovene, for example, -ks- (It. sassofono, Slo. saksofon, Eng. saxophone), -kt- (It. ottobre, Slo. oktober, Eng. October), -pt- (It. settembre, Slo. september, Eng. September), -mn- (It. autunno, Eng. autumn, where the consonant group - mn- persists only in writing['o:tm]).

${ }^{16}$ Here, Slovene is mentioned as the first language and English as the first foreign language of the study sample.
} 


\section{Guidelines for second and/or foreign language early literacy acquisition/instruction}

To planning, realization and monitoring of early literacy acquisition in a second/foreign language two factors are crucial: (i) identification of differences in transparency of writing systems of the learner's first and second/foreign language, and (ii) identification of levels of positive and negative transfer from the first to the second/foreign language.

Transparency of writing systems analysis provides teachers with precious information on strategies used by learners who learn to read and write in languages with a different level of transparency. With more transparent writing systems learners tend to develop mainly one strategy, i.e. the alphabetic strategy. The less transparent the writing system, the more strategies are developed to cope with diversity in phoneme-grapheme correspondences. For instance, learners who learn to read and write in English develop three different strategies: (i) analogy reading strategy to read and write words with the same on-set or rhyme (for example, light, right, might, fight, bright, knight), (ii) lexical reading strategy in recoding words with irregular written representation (for example, the, people, choir), (iii) alphabetic reading strategy to recode words with »regular « correspondences between phonemes and graphemes (for example, tin, cap, crop) (Goswami, 2002).

The identification of divergences in the two phonologies and writing systems shows which levels of phonology, phonological awareness and grapheme-morpheme correspondences acquisition may simply be transferred from the learner's first language (positive transfer) and which levels require systematic instruction as to prevent or at least limit the occurrence of the negative transfer.

The role of systematic literacy acquisition has been confirmed in a study carried out by the author with children learning Italian as second language in schools with Slovene as language of instruction. 140 children participated in the research that began their schooling in the school year 2001/2002 and attended the fourth grade in the school year 2004/2005. The research was carried out as a pedagogical experiment based on a single-factor model with two experimental factor modalities with the existent school classes as comparative groups (experimental and control group). Children in the experimental group were offered systematic literacy instruction in Italian: phonology, phonological awareness development and systematic learning of phoneme-grapheme correspondences with a particular stress on phonemes, graphemes and phonemegrapheme correspondences that differ in Italian with respect to Slovene. Effects of the introduction of systematic literacy instruction (the experimental factor) into the experimental group with respect to the control group were measured by means of phonological awareness testing and dictation. Study results based on empiric observation of experiential practice have confirmed that children learn to read and write significantly better when they receive systematic literacy instruction in a second/foreign language. 
Children in the experimental group achieved significantly better results on all contents and levels tested. ${ }^{17}$

\section{Conclusions}

Processes related to individual levels of literacy acquisition are understood provided there is knowledge of strategies one develops in these periods as well as mechanisms that enable beginner readers to progress to qualitatively higher levels of literacy. Study of literacy development models, beginner readers reading strategies, and intercultural diversities in early reading acquisition have made note of two essential language characteristics that give rise to the development of qualitatively different reading strategies: language phonology and orthography transparency. However, there are differences in reading literacy development dynamics within individual linguistic groups as well, i.e. differences that originate from children's environment, particularly their families, nursery schools and elementary schools. Schooling time is a particularly important period in literacy development when by means of appropriate programs all children progress, including children deprived of print at home. Modern early literacy teaching programs are thus based on the following suppositions: (i) early literacy acquisition is not merely reading and writing acquisition, rather it is a complex process of a balanced development of all communicative abilities in a literacy teaching communicative model, (ii) activities related to emerging literacy aiming at the development of reading and writing subskills in the pre-reading and prewriting period that make children ready to early reading acquisition are critical in this process, and (iii) reading and writing subskills development, particularly phonological awareness development influences significantly the development of early literacy and later also the development of reading at cognitively different levels of comprehension, general knowledge, memory and vocabulary.

\section{Bibliography}

Aslin, R.N., Saffran, J.R. in Newport, E.L. (1998).Computation of Conditional Probability Statistics by 8-Month-Old Infants. Psychological Science, 9 (4): 321-324.

Barrus Smith, S., Simmons, D.C. in Kameenui, E.J. (1995b).Phonological Awareness: Curricular and Instructional Implications for Diverse Learners. NCITE Research Synthesis: Reading and Diverse Learners. Technical Report no.22. http://idea.uoregon.edu/ ncite/ documents/techrep/tech22.html (12.7.2001).

Chard, D.J. in Dickson, S.V. (1999). Phonological awareness: Instructional and Assessment Guidelines. Intervention in School and Clinic. 34 (5): 261-270.

Cummins, J (2000). Language, Power and Pedagogy: Bilingual Children in the Crossfire. Multilingual Matters Ltd Clevedon, Buffalo, Toronto, Sydney: Cambrian Printers Ltd.

\footnotetext{
${ }^{17}$ Further reading: Zorman 2007b.
} 
Čok, L. (1994).Upovedovanje in učenjedrugegajezika v otroštvu: doktorska disertacija. 1. del (2 zv.), Ljubljana: Faculty of arts.

D'Angiulli, A., Siegel, L. in Serra, E. (2001). The Development of Reading in English and Italian in Bilingual Children.Applied Psycholinguistics 22 (4): 479-507

Durgunoglu, A.Y. (2002). Cross-linguistic transfer in literacy development and implications for language learners.Annals of Dyslexia, 51 (1): 189-204.

Durgunoglu, A.Y. in Öney, B. (2000). Literacy Development in Two Languages: Cognitive and Sociocultural Dimensions of Cross-Language Transfer. A Research Symposium on High Standards in Reading for Students From Diverse Language Groups: Research, Practice \& Policy. Proceedings. April 19-20, 2000. U.S. Department of Education.Office of Bilingual Education and Minority Languages Affairs. Washington, DC.

Ehri, L.C. (1998). Grapheme-Phoneme Knowledge is Essential for Learning to Read Words in English. V: Metsala, J.L. in Ehri, L.C. (ur.) (1998). Word Recognition in Beginning Literacy. New Jersey, London: Lawrence Erlbaum Associates, 3-40.

Ellis, N.C. in Hooper, A.M. (2001). Why Learning to Read is easier in Welsh than in English: Orthographic Transparency Effects Evinced with Frequency-Matched Tests. Applied Psycholinguistics, 22 (4): 571-599. Povzetek: http://journals.cambridge.org (17.7.2005).

Ferreiro, E. in Terebosky, A. (1979). Los sistemas de escritura en el desarrollodelniño. V italijanskemprevodu G. Noce (1985). La costruzionedella lingua scrittanel bambino. Firenze: Giunti.

Frith, U., Wimmer, H. in Landerl, K. (1998). Differences in Phonological Recoding in German and English-Speaking Children. Scientific Studies of Reading, 2(1): 31-54.

Giovanardi Rossi, P. in Malaguti T. (1994). Valutazione delle abilità di scrittura. Analisi dei livelli di apprendimento e deidisturbispecifici.6 zv. Trento: Erickson. $21-25$.

Golli, D. (1992). Psihološke osnove začetnega branja in pisanja. Pedagoška obzorja, 7 (19/20):

Goswami, U. (2002). Phonology, Reading development, and Dyslexia: A cross-linguistic perspective. Annals of Dyslexia, 51 (1): 139-163.

Goswami, U., Ziegler, J.C., Dalton, L. in Schneider W. (2001). Pseudohomophone Effects and Phonological Recoding Procedures in Reading Development in English and German. Journal of Memory and Language 45 (4): 648-664.

Harris, M. in Coltheart, M. (2003). L'elaborazione dell'inguaggionei bambini e negli adulti. Bologna: Il Mulino.

Heeren, W. (2004).Perceptual Development of a New Phoneme Contrast by Adult and 12-year old Listeners.Perceptual Development of Phonemes From Sound to Sense, June 11-13, 2004.

Hempenstall, K. (2000). Beyond phonemic awareness: The Role of Other Phonological abilities. Education News 5/9/2000. http://www.educationnews.org/beyond_phonemic_awareness. htm (8. 7. 2001).

Inagaki, K., Hatano, G. in Otake, T. (2000).The Effect of Kana Literacy Acquisition on the Speech Segmentation Unit Used by Japanese Young Children. Journal of Experimental Child Psychology, 75 (1): 70-91.

Iverson, P., Kuhl, P.K., Akahane-Yamada, R., Diesch, E., Tokhura, Y., Kettermann, A. in Siebert, C. (2002). A Perceptual Interference Account of Acquisition Difficulties for Non-Native Phonemes. Cognition 87 (1): B47-B57.

Kuhl, P. K. (2004). Early Language Acquisition: Cracking the Speech Code. Nature Reviews Neuroscience, 5 (11): 831-843.

Kuhl, P. K., Tsao, F. M., in Liu, H.-M. (2004). Foreign-Language Experience in Infancy: Effects of Short-Term Exposure and Social Interaction on Phonetic Learning. Proceedings of the National Academy of Sciences of the USA, 100 (15): 9096-9101. 
Magajna, L. (1993). Psihogenetski pristop k razvoju pismenosti. Psihološka obzorja, Vol. 2, no. 3/4, 117-122

Magajna, L (1995a). Razvoj bralnih strategij: vlog akognitivnega in fonološkega razvoja ter fonološke structure jezika. Doktorska disertacija. Ljubljana: Filozofskafakulteta.

Maye, J. in Weiss, D. (2003). Statistical Cues Facilitate Infants' Discrimination of Difficult Phonetic Contrasts. V Beachley, B. (ur.) BUCLD 27 Proceedings. Somerville: Cascadilla Press, 508518 .

McBride-Chang, C. in Kail, R. (2002).Cross-Cultural Similarities in the Predictors of Reading Acquisition. Child Development, 73 (5): 1392-1407.

McGuinness, C. in McGuinness, G. (1998). Reading reflex. New York: The free Press.

Oney, B. in Goldman, S. R. (1984). Decoding and Comprehension Skills in Turkish and English: Effects of Regularity of Grapheme-Phoneme Correspondences. Journal of Educational Psychology, 76 (4): 557-568. (2): 74-82.

Ropič, M. (2000a). Praktični problemi v začetnemo pismenjevanju. Sodobna pedagogika, 51

Rosner, (1975).Test of Auditory Analysis Skills.http://www.soar.gcps.k12.fl.us/pdfs/ rosner.pdf (13. 7. 2001).

Rostohar, M. (1961). Začetno čitanje poanalitični metodi. Ljubljana: DZS.

Saffran, J. R., Aslin, R. N. in Newport, E. L. (1996). Statistical Learning by 8-Month-Old Infants. Science, 274 (5294): 1926-1928.

Scalisi, T.G., Pelagaggi, D. in Fanini, S. (2003). Apprendere la lingua scritta: Le abilità di base. Roma: Carocci.

Seymour, P. H. K., Aro, M. in Erskine, J. M. (2003). Foundation Literacy acquisition in European Orthographies. British Journal of Psychology, 94 (2): 143-174.

Tai, L. H., Spinks, J. A., Eden, G. F., Perfetti, C. A. in Siok, W. T. (2005). Reading depends on writing, in Chinese. Proceedings of the National Academy of Sciences of the USA, 102 (24): 87818785 .

Tsukada, K. (2004). Cross-Language Perception of Final Stops in Thai and English: A Comparison of Native and Non-Native Listeners. Proceedings of the 10th Australian International Conference on Speech Science \& Technology Macquarie University, Sydney, December 8 to 10, 2004. Australian Speech Science \& Technology Association Inc, 563-568.

Ur, P. (1996). A Course in Language Teaching: Practice and Theory. Cambridge: Cambridge University Press.

Vellutino, F. R., Scanlon, D. M., Small, S. G. in Tanzman, M. S. (1991). The linguistic bases of reading ability: Converting written to oral language. V: Horowitz, R. (ur.) (1991). Studies of Orality and Literacy: Critical Issues for the Practice of Schooling. Berlin, New York: Mouton de Gruyter, 99132.

Werker, J. F. in Tees, R. C. (1984). Phonemic and Phonetic Factors in Adult Cross-Language Speech Perception.Journal of Acoustic Society of America, 75 (6): 1866-1878. Povzetek: http://www.ncbi.nlm.nih.gov/entrez/query.fcgi?cmd (24. 7. 2005).

Yopp, H. K. in Singer, H. (1995). Test of Phonemic Segmentation. http://teams.lacoe.edu/ reading/assessments/yopp.html (13. 7. 2001).

Ziegler, J. C. in Goswami, U. (2005). Reading Acquisition, Developmental Dyslexia and Skilled Reading Across Languages: A Psycholinguistic Grain Size Theory. Psychological Bulletin, 131 (1): 3-29.

Ziegler, J. C., Perry, C., Jacobs, A. M. in Braun, M. (2001). Identical Words are Read Differently in Different Languages. Psychological Science, 12 (5): 379-384. 
Zorman, A. (2007a). Model zaporednegazačetnegaopismenjevanja v drugem in/alitujem jeziku. Zgodnje učenje in poučevanje otrok 1, Zbirka Knjižnica Annales Majora. Koper: UP Znanstvenoraziskovalno središče RS, UP Pedagoška fakulteta Koper: Založba Annales, 265-285.

Zorman, A (2007b). Prepoznavanje glasov in spoznavanje njihovih pisnih ustreznic v maternem in drugemo ziroma tujem jeziku. Unpublished doctoral thesis. Univesity in Ljubljana, Faculty of Education.

Zorman, A. (2005). Glasovno zavedanje in razvojosno v nepismenosti v prvem, drugem/ tujem jeziku. Sodobna pedagogika, 56 (122), Posebna izdaja: 24-45.

Zorman, A. (2004a). Razvojosno v nepismenosti kot dvoredne strategije (de)kodiranja. Annales, Series historia et sociologia, 14 (2): 343-352.

Zorman, A. (2004b). Raziskovanje glasovnega zavedanja pri pouku drugega/tujega jezika. (Researching phonemic awareness in second/foreign language teaching). V: Cotič, M., MedvedUdovič, V., Felda, D., Zorman, A., Borota, B., Vičič, J., Starc, S., Zurc, J., ZudičAntonič, N. (ur.). (2004). Izvlečki. Koper: Univerzana Primorskem, Pedagoška fakulteta Koper, 40-41.

Metodički obzori 6(2011)1

Pregledni rad

UDK: 81'243:159.953.5

Primljeno: 1. 12. 2010.

\section{POTEŠKOĆE U UČENJU ČITANJA I PISANJA DRUGOG ILI STRANOG JEZIKA}

Dr. sc. Anja Zorman

Fakulteta za humanistične študije, Univerza na Primorskem (Slovenija) e-mail: anja.zorman@guest.arnes.si

\section{Sa žetak}

Znati čitati i pisati je kulturalna vrijednost svake osobe i društva općenito, i kao takva predstavlja osnovni faktor u modernom društvu jednog kreativnog i kvalitetnog života. Učenje čitanja i pisanja je, dakle, nezamjenjiva tema u poučavanju materinjeg jezika, drugog ili stranog jezika. Na temelju kontrastivne razlike pogrešaka i kroz teoretsko proučavanje, autorica izlaže poteškoće koje nastaju u višejezičnom učenju čitanja i pisanja.

Radi programiranja, realizacije $i$ praćenja učenja čitanja i pisanja $u$ drugom/stranom jeziku važno je identificirati: (1) razlike u transparentnosti pravopisa prvog jezika i drugog/stranog jezika učenika i (2) područja pozitivnog i negativnog prijenosa prvog jezika u drugi/strani jezik.

Ovdje prikazani rezultati razlika u transparentnosti pravopisa dvaju jezika nastavnicima daju dragocjene informacije o strategijama koje se razvijaju u pismenom kodiranju jezika $\mathrm{s}$ različitim stupnjem pravopisne transparentnosti. U jezicima $\mathrm{s}$ pravopisnom transparentnošću učenici razvijaju samo jednu strategiju, onu abecednog čitanja. Kako bi došli do raznolikosti u podudaranjima između fonema i grafema što je manje transparentan pravopis, razvija se više strategija. Primjerice, onaj tko uči čitati i pisati engleski jezik razvija tri različite strategije kodiranja: (1) strategiju čitanja po analogiji s riječima koje dijele početni i završni dio (na primjer, light, right, might, 
fight, hight, bright, knight), (2) strategiju leksičkog čitanja s riječima, nepravilan grafički prikaz (na primjer, people, choir) i (3) strategiju abecednog čitanja za riječi s „,pravilnim" podudaranjem između fonema i grafema (na primjer, tin, cap, crop) (Goswami, 2002).

Identifikacija razlike u fonologiji i pravopisu dva jezika pokazuje opsege fonologije, fonološke svjesnosti i učenja podudaranja između fonema i grafema koji se mogu jednostavno prenijeti iz prvog jezika u ciljni jezik (pozitivan prijenos), ali koji zahtijevaju sustavno poučavanje kako bi se spriječila ili barem ograničila pojava negativnog prijenosa.

Potreba sustavnog poučavanja čitanja i pisanja bila je utvrđena istraživanjem koje je provela autorica s djecom koja uče talijanski jezik kao drugi jezik u slovenskim školama priobalja. U istraživanju su sudjelovala 140 učenika koji su školske 2001./2002. godine pohađali prvi razred i školske 2004./2005. godine četvrti. Istraživanje je provedeno kao pedagoški eksperiment temeljen na modelu jednog faktora, s podjelom ispitanika na osnovu postojećih razreda (eksperimentalna i kontrolna grupa). Djeca eksperimentalne grupe sustavno su bila poučavana čitanju i pisanju na talijanskom jeziku: fonologija (slušanje), fonološka svjesnost (kognitivna sposobnost podešavanja fonologijskih dijelova različitih dimenzija) i učenje podudaranja između fonema i grafema s posebnim osvrtom na foneme, grafeme i podudaranje divergentnih fonema-grafema u talijanskom jeziku u odnosu na slovenski jezik. Učinci na početku sustavnog učenja čitanja i pisanja mjereni su s provjeravanjem fonološke svjesnosti i diktatom. Rezultati istraživanja potvrdili su da djeca bolje uče čitati i pisati u drugom/stranom jeziku ukoliko ih se sustavno poučava čitanju i pisanju upravo na tom jeziku. Djeca iz eksperimentalne grupe su u svim razinama koje su se provjeravale postigla bolje rezultate $u$ odnosu na one iz kontrolne grupe te je razlika između te dvije grupe definirana kao statistički značajna.

Najsuvremeniji programi poučavanja čitanja i pisanja temelje se na sljedećim pretpostavkama: (1) učenje čitanja i pisanja nije jednostavno učenje grafema, već se radi o uravnoteženom razvojnom procesu svih komunikativnih sposobnosti takozvanog komunikacijskog modela učenja čitanja i pisanja, (2) veliku važnost imaju aktivnosti radi razvoja djelomičnih kompetencija u razdoblju pred-čitanja i pred-pisanja (pismenost u nastajanju) čime se priprema djecu na organizirano učenje čitanja i pisanja u školi i (3) razvoj djelomičnih kompetencija, posebice fonološke svjesnosti, značajno utječu na razvoj učenja čitanja i pisanja, a u daljnjim etapama na razvoj čitanja različitih kognitivnih razina shvaćanja, na razvoj opće kulture, pamćenja i rječnika.

Ključne riječi: osnovna pismenost, prvi jezik, drugi jezik, strani jezik, metode početnog opismenjavanja, fonografska metoda, kontrastivna metoda

\section{PROBLEMI ZAČETNEGA OPISMENJEVANJA V DRUGEM ALI TUJEM JEZIKU}

\section{Povzetek}

Pismenost je kulturna vrednota posameznika in družbe ter sodi med poglavitne dejavnike kvalitetnega in ustvarjalnega življenja v sodobni družbi. Opismenjevanje je zato nenadomestljiva sestavina učenja materinščine, drugih in tujih jezikov. Avtorica predstavlja probleme, ki se pojavljajo pri večjezičnem opismenjevanju. Na osnovi kontrastivne analize napak $\mathrm{v}$ pisnih izdelkih govorcev drugega oziroma tujega jezika je avtorica oblikovala načela za razvijanje začetne pismenosti $\mathrm{v}$ drugem/tujem jeziku ter model večjezične pismenosti, katerega učinkovitost je preverila v praksi. Temeljna 
ugotovitev empirične analize se glasi, da mora biti začetno učenje branja in pisanja $\mathrm{v}$ drugem/tujem in tudi v prvem jeziku sistematično. Odrasli, ki v tem procesu spremljajo otroka pa bi morali poznati obdobja v njem in mehanizme, s katerimi bi ga popeljali na kakovostno višje ravni osnovne pismenosti.

Ključne besede: osnovna pismenost, prvi jezik, drugi jezik, tuji jezik, metode začetnega opismenjevanja, glasovno zavedanje, fonografska metoda, kontrastivna analiza. 